\title{
Plasma Enzymes Activity in Gir Cattle and Jaffarabadi Buffaloes at Different Ages
}

\author{
Ninan Jacob $^{1 *}$, J.S. Arya ${ }^{2}$ and P.U. Gajbhiye ${ }^{3}$ \\ ${ }^{1}$ Department of Veterinary Physiology, Rajiv Gandhi Veterinary Institute for Education and \\ Research, Puducherry, India \\ ${ }^{2}$ Department of Animal Physiology and Biochemistry, College of Veterinary Science \& A.H., \\ A.A.U., Anand, Gujarat, India \\ ${ }^{3}$ Cattle Breeding Farm, Junagadh Agricultural University, Junagadh, Gujarat, India
}

*Corresponding author

\begin{abstract}
A B S T R A C T
The study was conducted on male ( $1 \mathrm{wk}$ to $12 \mathrm{~m}$ age) and female ( $1 \mathrm{wk}$ to $36 \mathrm{~m}$ age) Gir cattle and Jaffarabadi buffaloes maintained on an organised farm. Age exerted significant

Keywords

Gir, Jaffarabadi,

Aspartate transaminase,

Alanine transaminase,

Lactate dehydrogenase

Article Info

Accepted:

16 March 2018

Available Online:

10 April 2018 $(\mathrm{P}<0.05)$ effect on AST, ALT and LDH activity in both the sexes of Gir and Jaffarabadi breed. AST values in adult Gir females at 24 and $36 \mathrm{~m}$ age were lesser than the values observed at 1 wk of age. The increase in AST as age increased was noted in Gir males. The effect of age on AST levels in Jaffarabadi females and males was found to be significant $(\mathrm{P}<0.05)$, with no definite pattern of increase or decrease as the age advanced. The activity of ALT increased as age advanced upto $12 \mathrm{~m}$ age in both males and females of Gir and in females of Jaffarabadi. Higher LDH activity was found in Jaffarabadi females as compared to Gir females at $24 \mathrm{~m}$ age. The levels in male Gir was significantly $(\mathrm{P}<0.05)$ higher at $1 \mathrm{wk}, 1$ and $3 \mathrm{~m}$ whereas it was significantly $(\mathrm{P}<0.05)$ lower at 6 and $12 \mathrm{~m}$ age as compared to the corresponding levels in Jaffarabadi males. Higher AST and ALT activity was observed in Jaffarabadi buffaloes as compared to Gir cattle at all ages whereas the LDH showed higher activity in Gir cattle as compared to Jaffarabadi buffaloes.
\end{abstract}

\section{Introduction}

Growth is the most important characteristic for livestock production as it is the foundation on which all other forms of production and reproduction rest. The biochemical changes taking place during various stages of growth have been attributed to the activities of various enzymes and hormones. Though the buffalo is considered similar to cattle, there exists many physiological and biochemical differences between them which is reflected through their production and reproduction performances. A comparative study was conducted on Gir cattle and Jaffarabadi buffalo to understand the difference in the activity of AST, ALT and LDH enzymes at various ages. The data on Jaffarabadi buffaloes is scant. An attempt is being made to establish base line data for future comparisons while working in these 
breeds. The reference values generated in this study would be useful to clinicians and researchers.

\section{Materials and Methods}

The study was carried out on male (at $1 \mathrm{wk}$ and 1, 3, 6, $12 \mathrm{~m}$ age) and female (at $1 \mathrm{wk}$ and $1,3,6,12,24,36 \mathrm{~m}$ age) Gir cattle and Jaffarabadi buffaloes maintained under standard feeding and managemental conditions at the Cattle Breeding Farm, Junagadh Agricultural University, Junagadh, Gujarat. The study was approved by the Institutional Animal Ethics Committee (IAEC). The animals were separated from the herd only for the duration of blood collection which was collected $(2 \mathrm{ml})$ aseptically through jugular venipuncture. Clear plasma was separated and plasma AST, ALT and LDH activities were determined by modified IFCC method (diagnostic kits manufactured by Crest Biosystems, Coral Clinical Systems, Goa) on BS-120 Chemistry Analyser (Mindray). Statistical analysis of the data was done using Completely Randomised Design (CRD) as described by Snedecor and Cochran (1990).

\section{Results and Discussion}

The values of plasma aspartate transaminase (AST), alanine transaminase (ALT) and lactate dehydrogenase $(\mathrm{LDH})$ in $\mathrm{IU} / \mathrm{ml}$ are presented in the Table.

\section{Plasma Aspartate Transaminase (AST - IU/ml)}

\section{Gir cattle}

In Gir females significant $(\mathrm{P}<0.05)$ differences were observed in AST levels at all ages studied. The value at $36 \mathrm{~m}$ age was nonsignificantly lower than that at $1 \mathrm{wk}$ of age. The value at $1 \mathrm{~m}$ age in Gir females and males was lower than at all other ages and significantly $(\mathrm{P}<0.05)$ differed from the values at $1 \mathrm{wk}$ and $3 \mathrm{~m}, 6 \mathrm{~m}$ and $12 \mathrm{~m}$ age. The levels in males were significantly ( $\mathrm{P}<$ 0.05 ) high at $12 \mathrm{~m}$ age as compared to other ages and stages. The levels in Gir males were significantly $(\mathrm{P}<0.05)$ lower than in females at 3 and $6 \mathrm{~m}$ age and were non-significantly lower at $1 \mathrm{wk}$ and $1 \mathrm{~m}$ age.

\section{Jaffarabadi buffaloes}

In Jaffarabadi females and males, significantly $(\mathrm{P}<0.05)$ lower value was recorded at $1 \mathrm{~m}$ from that of all other ages. The levels dropped significantly $(\mathrm{P}<0.05)$ from $1 \mathrm{wk}$ to $1 \mathrm{~m}$ age, and then increased significantly $(\mathrm{P}<0.05)$ at 3 $\mathrm{m}$. In females, the value observed at $36 \mathrm{~m}$ age was significantly $(\mathrm{P}<0.05)$ higher than that observed at all other ages. In males, significant $(\mathrm{P}<0.05)$ decline was noted at 12 $\mathrm{m}$ age from that at $6 \mathrm{~m}$ age. Significantly $(\mathrm{P}<$ $0.05)$ higher and lower values were observed at $6 \mathrm{~m}$ and $12 \mathrm{~m}$ age, respectively in Jaffarabadi males as compared to Jaffarabadi females.

\section{Between Gir cattle and Jaffarabadi buffaloes}

Significantly $(\mathrm{P}<0.05)$ higher levels were recorded at all ages in Jaffarabadi females and males as compared to Gir females and males, except at $12 \mathrm{~m}$ age where values were nonsignificantly higher in Jaffarabadi males than the corresponding value in Gir cattle.

The findings were in line with those reported by Sharma and Bisoi (1995) whereas Atak et al., (2000) and Sahu et al., (2009) reported that AST levels increased as age increased. The increase in AST as age increased in Gir males was similar to the finding of Sahu et al., (2009) in new born calves.

The effect of age in Jaffarabadi females and males was found to be significant, with no 
definite pattern of increase or decrease as the age advanced. However, Rathee et al., (2002) found no significant effect of age on AST levels in their studies. This could be due to different age groups and breeds of buffaloes used in their study. The values obtained at different ages and physiological stages in Jaffarabadi buffaloes in our study was higher than those reported by Amer and Hashem (2008) and Abd Ellah (2011) in Egyptian buffaloes. Since no literature was traceable regarding breed differences, the comparative study between Gir cattle and Jaffarabadi buffaloes remain uncompared.

As AST enzyme activity is indicative of increased physiological activity of the tissue, a significant relationship in the level of these enzymes exist with body weight, physiological conditions and rhythmic reproductive function (Pal et al., 1991). The higher levels of AST in Jaffarabadi buffaloes as compared to Gir cattle could be due to their higher body weight at the corresponding ages and physiological stages, indicating increased muscular and hepatic activity in Jaffarabadi buffaloes.

\section{Plasma Alanine Transaminase (ALT - IU/ml)}

\section{Gir cattle}

In Gir females and males, the levels decreased non-significantly at $1 \mathrm{~m}$ from that at $1 \mathrm{wk}$ age. The values increased significantly $(\mathrm{P}<0.05)$ at $3 \mathrm{~m}$ age, then decreased non-significantly at $6 \mathrm{~m}$ age and again increased significantly $(\mathrm{P}<$ $0.05)$ at $12 \mathrm{~m}$ from the value at $6 \mathrm{~m}$ age. In females, the level at $36 \mathrm{~m}$ age was significantly $(\mathrm{P}<0.05)$ higher than that observed at $1 \mathrm{wk}$ and $1 \mathrm{~m}$ age. Comparing the males and females of Gir cattle, it was noted that plasma alanine transaminase was lower in males than in females at all the ages studied with significant $(\mathrm{P}<0.05)$ difference noted at 1 and $12 \mathrm{~m}$ ages.

\section{Jaffarabadi buffaloes}

In Jaffarabadi females and males, nonsignificant decrease was noted at $1 \mathrm{~m}$ from the level at 1 wk age. The levels increased significantly $(\mathrm{P}<0.05)$ at $3 \mathrm{~m}$ from that at $1 \mathrm{~m}$ age. A significantly $(\mathrm{P}<0.05)$ higher level was noted in females at $36 \mathrm{~m}$ age from the levels at other ages studied. The levels in Jaffarabadi males were higher than in females at all ages except at $12 \mathrm{~m}$ age.

\section{Between Gir cattle and Jaffarabadi buffaloes}

The values in Jaffarabadi females as compared to Gir females were significantly $(\mathrm{P}<0.05)$ higher at $1 \mathrm{wk}, 1,6$ and $36 \mathrm{~m}$ age and were non-significantly higher at 3 and $24 \mathrm{~m}$ age. The levels in Jaffarabadi males was significantly $(\mathrm{P}<0.05)$ higher than that in Gir males at all ages except at $12 \mathrm{~m}$ age where it was significantly $(\mathrm{P}<0.05)$ lower. The age had significant effect on ALT levels in Gir females and male calves used in our study. The findings agreed with those of Sharma and Bisoi (1995) whereas Atak et al., (2000) and Sahu et al., (2009) found no age difference in their studies. Plasma alanine transaminase levels in Jaffarabadi buffaloes obtained in our studies were in the range as reported by Rathee et al., (2002), Nandi et al., (2010) and Abd Ellah et al., (2011) in various breeds of buffaloes. Significant effect of age on ALT was in agreement with the finding of Rathee $e t$ al., (2002).

The increasing levels of ALT as age advanced upto $12 \mathrm{~m}$ age in both males and females of Gir and females of Jaffarabadi species could be ascribed to the increase in peripheral concentration of gonadal hormones during corresponding periods (Sharma, 1996). Comparatively, higher activity of ALT in adults than in calves agreed with the findings of Prava et al., (2012). 
Table.1 Plasma Aspartate Transaminase (AST - IU/ml), Alanine Transaminase (ALT - IU/ml) and Lactate Dehydrogenase (LDH - IU/ml) activity at different ages in Gir cattle and Jaffarabadi buffaloes (Mean \pm S.E.)

\begin{tabular}{|c|c|c|c|c|c|c|c|c|}
\hline \multirow{2}{*}{\multicolumn{2}{|c|}{$\begin{array}{c}\text { Age } \\
\text { Animal }\end{array}$}} & \multirow{2}{*}{$\begin{array}{c}\text { Wk } \\
1\end{array}$} & \multicolumn{6}{|c|}{ Months } \\
\hline & & & 1 & 3 & 6 & 12 & 24 & 36 \\
\hline \multicolumn{9}{|c|}{ Plasma Aspartate Transaminase } \\
\hline \multirow[t]{2}{*}{$\mathbf{G}$} & $\mathbf{F}$ & $\begin{array}{l}58.19^{b t} \\
\pm 6.53\end{array}$ & $\begin{array}{l}45.56^{\text {at }} \\
\pm 2.61\end{array}$ & $\begin{array}{c}68.83^{\text {ctx }} \\
\pm 3.44\end{array}$ & $\begin{array}{c}59.61^{\text {bctx }} \\
\pm 2.11\end{array}$ & $\begin{array}{l}68.19^{c t} \\
\pm 2.07\end{array}$ & $\begin{array}{l}47.21^{\text {at }} \\
\pm 2.72\end{array}$ & $\begin{array}{c}51.29^{\mathrm{abt}} \\
\pm 2.66\end{array}$ \\
\hline & $\mathbf{M}$ & $\begin{array}{c}50.15^{b v} \\
\pm 2.64\end{array}$ & $\begin{array}{c}39.23^{\mathrm{av}} \\
\pm 1.80\end{array}$ & $\begin{array}{c}52.33^{\text {bvy }} \\
\pm 3.03\end{array}$ & $\begin{array}{c}51.69^{\text {bvy }} \\
\pm 1.77\end{array}$ & $\begin{array}{l}69.59^{c} \\
\pm 2.25\end{array}$ & - & - \\
\hline \multirow[t]{2}{*}{$\mathbf{J}$} & F & $\begin{array}{c}105.01^{\mathrm{cu}} \\
\pm 4.84\end{array}$ & $\begin{array}{c}66.56^{\mathrm{au}} \\
\pm 2.39\end{array}$ & $\begin{array}{c}103.79 \\
\mathrm{cu} \pm 5.02\end{array}$ & $\begin{array}{c}97.96^{\text {bcux }} \\
\pm 4.75\end{array}$ & $\begin{array}{c}87.29^{\text {bux }} \\
\pm 4.29\end{array}$ & $\begin{array}{c}87.53^{b u} \\
\pm 4.10\end{array}$ & $\frac{123.39^{\mathrm{d}}}{\mathrm{u} \pm 6.54}$ \\
\hline & $\mathbf{M}$ & $\begin{array}{c}102.81^{\mathrm{cw}} \\
\pm 4.11\end{array}$ & $\begin{array}{c}68.28^{a w} \\
\pm 3.47\end{array}$ & $\begin{array}{c}97.05^{b c w} \\
\pm 3.40\end{array}$ & $\begin{array}{c}138.02^{d w} \\
y=5.75\end{array}$ & $\begin{array}{c}72.75^{\mathrm{ay}} \\
\pm 2.62\end{array}$ & - & - \\
\hline \multicolumn{9}{|c|}{ Plasma Alanine Transaminase } \\
\hline \multirow[t]{2}{*}{$\mathbf{G}$} & $\mathbf{F}$ & $\begin{array}{l}17.25^{\text {at }} \\
\pm 0.72\end{array}$ & $\begin{array}{c}16.59^{\text {atx }} \\
\pm 0.86\end{array}$ & $\begin{array}{l}29.80^{c} \\
\pm 1.20\end{array}$ & $\begin{array}{c}26.20^{b c t} \\
\pm 1.13\end{array}$ & $\begin{array}{c}36.28^{d x} \\
\pm 1.46\end{array}$ & $\begin{array}{c}25.10^{b} \\
\pm 1.31\end{array}$ & $\begin{array}{c}23.97^{b t} \\
\pm 1.22\end{array}$ \\
\hline & $\mathbf{M}$ & $\begin{array}{c}16.05^{\mathrm{av}} \\
\pm 0.94\end{array}$ & $\begin{array}{c}13.42^{\text {avy }} \\
\pm 0.67\end{array}$ & $\begin{array}{c}27.10^{b c v} \\
\pm 1.89\end{array}$ & $\begin{array}{c}24.25^{\mathrm{bv}} \\
\pm 0.46\end{array}$ & $\begin{array}{c}31.20^{\mathrm{cvy}} \\
\pm 1.43\end{array}$ & - & - \\
\hline \multirow[t]{2}{*}{$\mathbf{J}$} & $\mathbf{F}$ & $\begin{array}{c}24.10^{\text {au }} \\
\pm 1.25\end{array}$ & $\begin{array}{c}22.76^{\text {au }} \\
\pm 1.19\end{array}$ & $\begin{array}{l}33.08^{b} \\
\pm 1.70\end{array}$ & $\begin{array}{c}32.93^{\text {bux }} \\
\pm 1.96\end{array}$ & $\begin{array}{c}33.19^{b x} \\
\pm 2.05\end{array}$ & $\begin{array}{l}26.92^{a} \\
\pm 1.33\end{array}$ & $\begin{array}{l}42.74^{\mathrm{cu}} \\
\pm 1.95 \\
\end{array}$ \\
\hline & $\mathbf{M}$ & $\begin{array}{c}28.43^{\mathrm{ab}} \\
\mathrm{w} \pm \\
2.01\end{array}$ & $\begin{array}{c}25.33^{\text {aw }} \\
\pm 1.44\end{array}$ & $\begin{array}{c}33.70^{b w} \\
\pm 1.69\end{array}$ & $\begin{array}{c}64.41^{\mathrm{cwy}} \\
\pm 3.34\end{array}$ & $\begin{array}{c}25.49^{\text {awy }} \\
\pm 1.88\end{array}$ & - & - \\
\hline \multicolumn{9}{|c|}{ Plasma Lactate Dehydrogenase } \\
\hline \multirow[t]{2}{*}{$\mathbf{G}$} & $\mathbf{F}$ & $\begin{array}{c}884.87^{t} \\
x \pm \\
24.78\end{array}$ & $\begin{array}{l}941.84^{t x} \\
\pm 23.80\end{array}$ & $\begin{array}{l}886.96^{t} \\
\pm 25.85\end{array}$ & $\begin{array}{l}915.61^{t x} \\
\pm 20.22\end{array}$ & $\begin{array}{l}898.31^{t x} \\
\pm 30.09\end{array}$ & $\begin{array}{l}869.62^{t} \\
\pm 20.83\end{array}$ & $\begin{array}{c}918.54 \\
\pm 26.58\end{array}$ \\
\hline & $\mathbf{M}$ & $\begin{array}{c}678.82^{a} \\
\text { vy } \pm \\
26.62\end{array}$ & $\begin{array}{l}795.11^{\text {bcv }} \\
\pm 39.98\end{array}$ & $\begin{array}{c}902.32^{d} \\
{ }^{d} \\
22.89\end{array}$ & $\begin{array}{c}739.39^{\text {avy }} \\
\pm 29.50\end{array}$ & $\begin{array}{c}707.46 \\
\text { avy } \\
\pm \\
12.63\end{array}$ & - & - \\
\hline \multirow[t]{2}{*}{$\mathbf{J}$} & $\mathbf{F}$ & $\begin{array}{c}553.50^{\mathrm{a}} \\
\mathrm{ux} \pm \\
\mathbf{1 2 . 1 1}\end{array}$ & $\begin{array}{l}664.39^{b c u} \\
x^{\mathrm{x}} \pm 19.09\end{array}$ & $\begin{array}{c}633.42 \\
\text { bu } \pm \\
18.09\end{array}$ & $\begin{array}{l}719.89^{c d u} \\
x \pm 19.96\end{array}$ & $\begin{array}{c}772.33^{d u} \\
\pm 21.26\end{array}$ & $\begin{array}{c}935.47^{\mathrm{e}} \\
\mathbf{u} \pm \\
21.92\end{array}$ & $\begin{array}{l}906.35^{\mathrm{e}} \\
\pm 24.74\end{array}$ \\
\hline & $\mathbf{M}$ & $\begin{array}{c}496.64^{\mathrm{a}} \\
\mathrm{wy} \pm \\
15.96\end{array}$ & $\begin{array}{c}482.23 \\
\text { awy } \pm \\
20.28\end{array}$ & $\begin{array}{c}573.89^{b} \\
w \pm \\
20.28\end{array}$ & 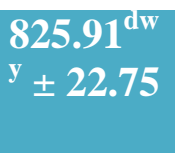 & $\begin{array}{c}813.11^{d w} \\
\pm 23.68\end{array}$ & - & - \\
\hline
\end{tabular}

Note: Means having the same superscript do not differ significantly from each other $(\mathrm{P}>0.05)$.

$\mathrm{F}: \mathrm{n}=8 ; \mathrm{M}: \mathrm{n}=6$.

Superscripts:

a - e: between females and between males of each breed

$\mathrm{t}-\mathrm{u}$ : between Gir females and Jaffarabadi females

$\mathrm{v}-\mathrm{w}$ : between Gir males and Jaffarabadi males

$x-y$ : between male and female of each breed 
The varying activity of ALT enzyme could also be indicative of increased physiological activity of the tissue at different ages and physiological stages.

The findings, in our concurrent study on the same species, of higher cortisol, ALP (Alkaline Phosphatase) and low ALT levels at $1 \mathrm{wk}$ of age and subsequent reversal in their levels as age progressed is supported by the findings of Bahga et al., (2009) who noted that stress reduces growth rate and lower ALT activity indicates lower amino acid turnover while higher alkaline phosphatase activity is an indicator of bone resorption/alkalosis.

Stress may also cause decreased activity of ALT and alkalosis as indicated by higher alkaline phosphatase activity.

The correspondingly higher levels of AST and ALT in Jaffarabadi buffaloes as compared to Gir cows at all ages and physiological conditions could be a reflection of higher body weight in Jaffarabadi buffaloes due to more body mass, hepatic and tissue activity.

\section{Plasma Lactate Dehydrogenase (LDH - IU/ml)}

\section{Gir cattle}

The range of plasma lactate dehydrogenase $(\mathrm{IU} / \mathrm{ml})$ in Gir females was from $884.97 \pm$ 24.78 (1 wk age) to $918.54 \pm 26.53(36 \mathrm{~m}$ age) at all ages The levels increased nonsignificantly from $1 \mathrm{wk}$ of age to $36 \mathrm{~m}$ of age.

Plasma lactate dehydrogenase (IU/ml) at all ages ranged from $678.82 \pm 26.62$ (1 wk age) to $902.32 \pm 22.89$ ( $3 \mathrm{~m}$ age $)$ in Gir males. The levels at $3 \mathrm{~m}$ age were higher than those at 1 wk of age. The values decreased significantly $(\mathrm{P}<0.05)$ from $3 \mathrm{~m}$ to $6 \mathrm{~m}$ age and further decreased non-significantly at $12 \mathrm{~m}$ age.
The values in Gir males were significantly ( $\mathrm{P}$ $<0.05)$ lower at all ages than in Gir females, except at $3 \mathrm{~m}$ age where it was nonsignificantly higher in the males than in the females.

\section{Jaffarabadi buffaloes}

The activity of plasma lactate dehydrogenase $(\mathrm{IU} / \mathrm{ml})$ at all ages ranged from $553.50 \pm$ 12.11 (1 wk age) to $935.47 \pm 21.92(24 \mathrm{~m}$ age), in Jaffarabadi females. The activity increased significantly $(\mathrm{P}<0.05)$ from $1 \mathrm{~m}$ age to that of $36 \mathrm{~m}$ age. The levels at $36 \mathrm{~m}$ age were significantly $(\mathrm{P}<0.05)$ higher than that at all other ages.

In Jaffarabadi males, plasma lactate dehydrogenase $(\mathrm{IU} / \mathrm{ml})$ levels at all ages ranged from $482.23 \pm 20.28(1 \mathrm{~m}$ age $)$ to $825.91 \pm 22.75$ (6 $\mathrm{m}$ age). The activity showed a continuous significant $(\mathrm{P}<0.05)$ increase from $1 \mathrm{wk}$ to $12 \mathrm{~m}$ age.

The values noted at $1 \mathrm{wk}$ and $1 \mathrm{~m}$ age were significantly $(\mathrm{P}<0.05)$ lower and that recorded at $3 \mathrm{~m}$ age was non-significantly lower in Jaffarabadi males compared to the females.

Significantly $(\mathrm{P}<0.05)$ higher values were noted at 6 and $12 \mathrm{~m}$ age in Jaffarabadi males than in females of these ages.

\section{Between Gir cattle and Jaffarabadi buffaloes}

On comparing the plasma lactate dehydrogenase activity in females of Gir and Jaffarabadi it was detected that the values at 1 wk, 1, 3, 6 and $12 \mathrm{~m}$ were significantly ( $\mathrm{P}<$ 0.05 ) higher and that at $36 \mathrm{~m}$ was nonsignificantly higher in Gir females as compared to Jaffarabadi females. Higher activity was found in Jaffarabadi females as compared to Gir females at $24 \mathrm{~m}$ age. 
The levels in male Gir was significantly ( $\mathrm{P}<$ 0.05 ) higher at $1 \mathrm{wk}, 1$ and $3 \mathrm{~m}$ whereas it was significantly $(\mathrm{P}<0.05)$ lower at 6 and 12 $\mathrm{m}$ age as compared to the corresponding levels in Jaffarabadi males.

The levels of LDH estimated in our studies in Gir females was in the range reported by Sharma and Bisoi (1995), Somarendro and Kumar (2006) and Samanta and Dass (2007). However, they were lesser than the values reported by Atak et al., (2000). Doornenbal et al., (1988) reported that ACP increased with age in Shorthorn cows, which was in agreement with our results. The activity of $\mathrm{LDH}$ in Gir male calves remained uncompared due to non-traceability of literature on similar lines.

The range of LDH in Jaffarabadi females and males obtained in our study was much higher than that reported by Amer and Hashem (2008) and Abd Ellah (2011) in Egyptian buffaloes. However, the levels in Jaffarabadi females and males at different ages and physiological stages reported in our study remain uncompared due to non-availability of literature on similar lines in buffaloes.

Lactate Dehydrogenase (LDH) which is mainly present in the myocardial cells is also widespread in body cells (Chatterjea and Shinde, 2008). The rise in its activity as age increased in both the genders of Gir cattle and Jaffarabadi buffaloes could be a pointer to its relationship with body weight. Since the values remain uncompared especially in Jaffarabadi buffaloes, it is suggested that the current observations may act as a baseline for future research on similar lines.

Age had a significant $(\mathrm{P}<0.05)$ effect on AST, ALT and LDH levels in both females and males of Gir cattle and Jaffarabadi buffaloes. Higher levels of AST and ALT were observed in Jaffarabadi buffaloes in both the sexes at all ages as compared to Gir Cattle, whereas LDH levels were higher in Gir cattle as compared to Jaffarabadi buffaloes. The reference values obtained here would provide a baseline for comparative study in these species in future and would be useful to clinicians and researchers.

\section{Acknowledgements}

Authors are thankful to the Director of Research and authorities of Junagadh Agricultural University, and to the Director of Research - Anand Agricultural University and Dean, College of Veterinary Science and Animal Husbandry, Anand for the permission and facilities provided to conduct the research work.

\section{References}

Abd Ellah, M.R. 2011. Serum metabolic profile of idiopathic emaciated buffaloes. Journal of Animal and Veterinary Sciences, 10(18): 2456 2458.

Amer, H. and Hashem, M. 2008. Relationship between clinical and biochemical picture of uterine torsion in Egyptian buffaloes (Bubalus bubalis). The Internet Journal Veterinary Medicine, 4(1): 14 - 31.

Atak, B.V., Talvelkar, B.A., Deshmukh, B.T., Nagvekar, A.S., Patil, S.P. 2000. Serum enzyme profile during growth in gir and crossbred calves. Indian Veterinary Journal, 77(4): 296-299

Bahga, C.S., Sikka, S.S. and Saijpal, S. 2009. Effect of seasonal stress on growth rate and serum enzyme levels in young crossbred calves. Indian Journal of Animal Research, 43(4): 288-290.

Chattaerjea, M.N. and Shinde, R. 2008. Textbook of Medical biochemistry. Section five - Clinical biochemistry. $7^{\text {th }}$ ed. Pub. Jaypee brothers Medical 
Publishers (P) Ltd., New-Delhi. Pp. 597 -608 .

Doornenbal, H., Tong, A.K.W. and Murray, N.L. 1988. Reference Values of Blood Parameters in Beef Cattle of Different Ages and Stages of Lactation. Canadian Journal of Veterinary Research, 52: 99105

Nandi, S., Mangle, L. and Mangle, N.S. 2010. Plasma levels of transaminases in normal and pyretic buffaloes. Indian Journal of Field Veterinarians, 6(1): 2122.

Pal, S.K., Mohanty, B.N., Ray, S.K.H. and Mohanty, D.N. 1991. Studies on serum protein, cholesterol and certain enzymes in relation to reproductive status in bovine females. Indian Journal of Animal Reproduction, 12(1): 28 - 29.

Prava, M., Dixit, N.K. and Tolankhomba, T.C. 2012. Effects of age and season on plasma enzyme activities of Frieswal cattle. Indian Veterinary Journal, 89(6): $66-68$.

Rathee, S.S., Garg, S.L., Rose, M.K., and Agarwal, V.K. 2002. Aminotransferases profile in female buffalo calves from birth to puberty. Indian Journal of Animal Sciences, 72(5): 393394.
Sahu, D., Singh, H.S. and Mishra, A. 2009. Effect of E. officinalis on physiological and liver function enzymes in normal growing calves. Indian Journal of Animal Physiology, 4(1): $19-22$.

Samanta, A.K. and Dass, R.S. 2007. Effect of Vitamin E supplementation on growth, nutrient utilization, blood biochemical and enzymatic profile in male crossbred (Bos indicus $\mathrm{x}$ Bos Taurus) calves. International Journal of Cow Science, 3(1\&2): 34-43.

Sharma, M and Bisoi, P.C. 1995. Clinically important serum enzymes of indigenous cattle. Indian Veterinary Journal, 72:2124.

Sharma, S. 1996. Studies on hormonal and blood biochemical profile of female buffalo calves as a function of age. M.V.Sc. Thesis submitted to CCSHAU, Hisar.

Snedecor, G.W. and Cochran, W.G. 1990. Statistical Methods, $8^{\text {th }}$ ed. Iowa State University Press, Iowa, USA.

Somarendro Singh, A. and Nirmal Kumar Singh, O. 2006. Blood biochemical and enzyme profile in oestrus and anoestrus heifers. Indian Veterinary Journal, 83(7): 726-729.

\section{How to cite this article:}

Ninan Jacob, J.S. Arya and Gajbhiye, P.U. 2018. Plasma Enzymes Activity in Gir Cattle and Jaffarabadi Buffaloes at Different Ages. Int.J.Curr.Microbiol.App.Sci. 7(04): 1977-1983. doi: https://doi.org/10.20546/ijcmas.2018.704.227 